\title{
Generalized Eruption Accompanied by Hepatitis in Two Thai Metal Cleaners Exposed to Trichloroethylene
}

\author{
Sompis PANTUCHAROENSRI ${ }^{1 *}$, Piyathida BOONTEE ${ }^{2}$, Preeyanun LIKHITSAN ${ }^{1}$, \\ Chantana PADUNGTOD ${ }^{3}$ and Somchai PRASARTSANSOUI ${ }^{4}$
}

\author{
${ }^{1}$ National Institute for the Improvement of Working Conditions and Environment, Department of Labour Protection \\ and Welfare, 22/23 Boromrachachonnee Hwy., Thaling-chan, Bangkok 10170, Thailand \\ ${ }^{2}$ Rajavithi Hospital, Rajavithi Road, Rajathewi, Bangkok 10400, Thailand \\ ${ }^{3}$ Bureau of Occupational and Environmental Disease, Department of Disease Control, Ministry of Public Health, \\ Tivanond road, Nonthaburi 11000, Thailand \\ ${ }^{4}$ Bureau of Epidemiology, Department of Disease Control, Ministry of Public Health, Tivanond road, Nonthaburi \\ 11000, Thailand
}

Received October 29, 2001 and accepted June 14, 2004

\begin{abstract}
Two female workers, aged 23 and 24, engaged in cleaning metal straps with trichloroethylene (TCE) in a watch manufacturing plant, experienced generalized eruption, mucosal lesion, fever and hepatitis. The first case suffered fulminant hepatitis and died from liver failure in two weeks after the first symptom appearance. The second case, whose onset of generalized eruption, mucosal lesion and hepatitis without jaundice was nine days after that of the first case, however, recovered in $2 \mathrm{wk}$. Because the result of working environment measurement suggested heavy exposure to TCE, we deemed that there would be a causal relationship between TCE exposure and the illness. Although there have been considerable number of papers describing the above-mentioned relationship, the fact is not well recognized even among medical personnel in Thailand. Taking the wide use of TCE into account, the prevention of this illness would be very important especially in rapidly industrializing countries.
\end{abstract}

Key words: Trichloroethylene, Cleaning process, Generalized skin eruption, Fulminant hepatitis

Since the 1960s, generalized skin and mucosal membrane lesions similar to Stevens-Johnson syndrome (SJS) accompanied by acute hepatitis in workers exposed to trichloroethylene (TCE) have appeared in literatures sporadically $^{1-6)}$. But there is an increasing tendency in the number of case reports of the health disorder from Asian countries since the middle of $1980 \mathrm{~s}^{6}$, and mass outbreaks were disclosed in the Philippines ${ }^{7)}$ and China ${ }^{8)}$. In Thailand, there has been only one case report of the same type of illness. The case was an 18 year-old female worker who cleaned socks by spraying $\mathrm{TCE}^{9)}$. She experienced generalized eruption and hepatitis and recovered rapidly after exposure cessation. Recently we encountered two cases suffering from

\footnotetext{
*To whom correspondence should be addressed.
}

the same illness among the workers who cleaned watchstrap made of metal and exposure condition to TCE was investigated.

TCE has been widely used in industries in Southeast Asian countries including Thailand. This paper aims to report two cases of TCE poisoning and to increase the awareness on this illness among employers, employees and medical personnel.

The first case was a single healthy 24-year-old woman. Recruited on 16 May 2000, she was employed as a metal strap polisher where about 130 employees were in the same department. Her task was to polish metal straps with a motor grinder and to clean afterwards by wiping them with TCE in an opened $200 \mathrm{ml}$ container. There was a local exhaust ventilation system at every motor grinder to remove dust 


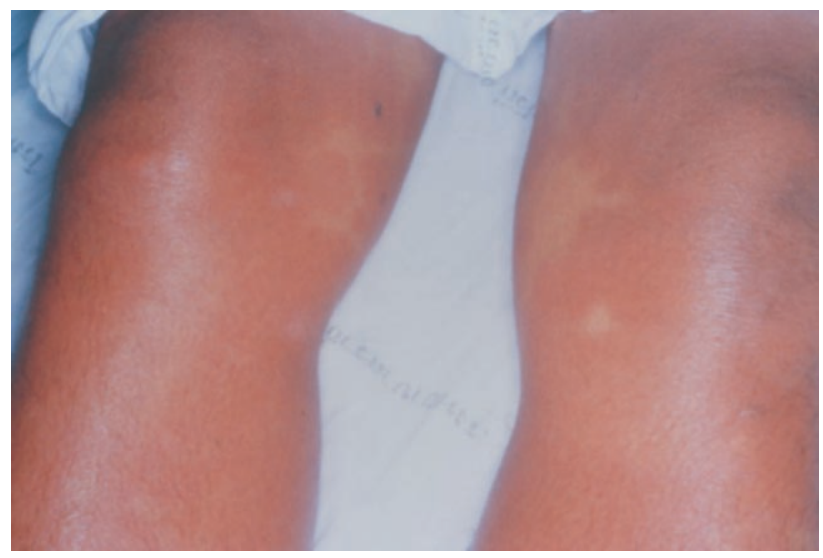

Fig. 1. Erythematous macuropapule of the second case.

generated by the process.

The next processes involved washing the straps by dipping them into a $60^{\circ} \mathrm{C}$ TCE tank outside working room for approximately $5 \mathrm{~min}$, air-dried and placed for inspection in polishing room which was air-conditioned.

The three TCE tanks were placed outside of the polishing room near the slots of glass windows. Two of them had local exhaust ventilation but without covers or air filters while the third one was not equipped with ventilation system. Consequently, the exhausted TCE vapor could flow back to the workplace. No ventilation system was provided at airdrying areas.

We were unable to confirm whether this worker had ever dipped the straps in TCE tanks or not. All workers in polishing section wore cloth masks and cloth gloves. Usually they worked eight hours per day, six days per week, and overtime for three hours per day when needed.

After working for five weeks, on 22 June 2000, the worker experienced dizziness, itching, fine red rash on lips, maxilla and creases at both knees. Upon hospital admission, 3 July 2000, she presented signs and symptoms of Stevens-Johnson syndrome (SJS), such as edema of both eyelids, erythematous swelled skin all over the body, mild fever, and hepatomegaly. On 11 July 2000, about 2 wk after quitting her job, trichloroacetic acid (TCA) in urine was $4.8 \mu \mathrm{g} / \mathrm{dl}$. She had died of fulminant hepatitis and septicemia on 15 July 2000.

The second case, a female aged 23, was recruited on 1 June 2000 and worked in the same section and sitting nearby the first case. During work she noticed the odor of TCE from $200 \mathrm{ml}$ containers. She used a cloth mask and cloth gloves, but there was skin contact with TCE during wiping straps with TCE and when she was intermittently assigned to dip the straps into TCE tanks.

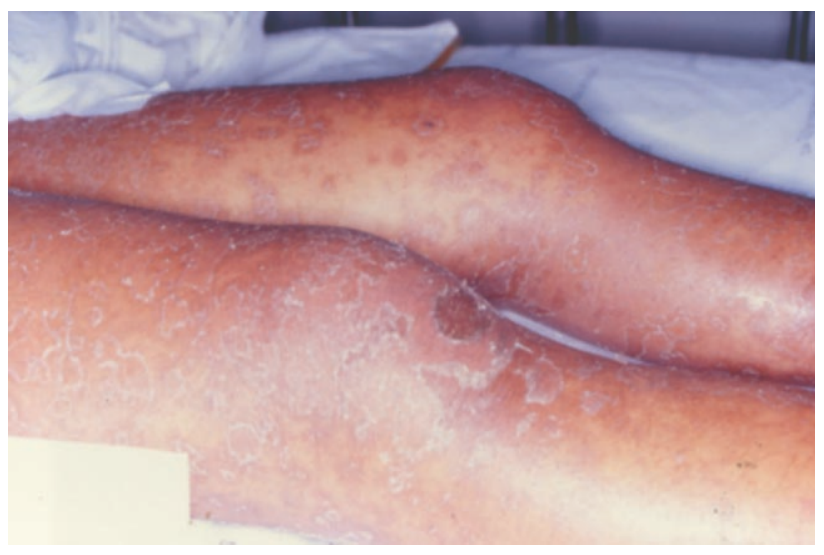

Fig. 2. Scaling during healing stage of the second case.

On 1 July 2000, after working overtime ( $3 \mathrm{~h}$ per day) for a week, pruritic eruptions appeared on her back and face and continued to her shoulder and hip together with several ulcers in her mouth.

The onset of the skin lesion of the second case was nine days after that of the first case. She visited a physician on 8 July 2000 and skin biopsy was performed. She continued to work for $4 \mathrm{~d}$ before being hospitalized on 14 July 2000 . In the meantime, she developed fever, nausea, and generalized erythematous plaques on her arms, trunks and legs (Fig. 1) with oral involvement. Since her symptoms were similar to those of the first case, trichloroacetic acid (TCA) in urine was analyzed on 14 July 2000 (four days after the cessation of exposure to TCE), and its level was $81.85 \mu \mathrm{g} / \mathrm{dl}$.

The patient had neither past histories of eruption due to medicine, food hypersensitivity nor alcohol drinking habit. On 14 July 2004, her serum hepatic enzymes were almost normal (glutamic pyruvic transaminase $16 \mathrm{IU} / \mathrm{L}$, glutamic oxaloacetic transaminase $17 \mathrm{IU} / \mathrm{L}$ and alkaline phosphatase $49 \mathrm{IU} / \mathrm{L}$ ) and urinary findings were not striking except WBC 40-50 cell/HPF. Liver function tests, at $11 \mathrm{~d}$ later, were deteriorated (glutamic pyruvic transaminase $388 \mathrm{IU} / \mathrm{L}$, glutamic oxaloacetic transaminase $260 \mathrm{IU} / \mathrm{L}$ and alkaline phosphatase $165 \mathrm{IU} / \mathrm{L})$. Three cycles of hemodialysis were given and she recovered steadily with scaling of the skin as shown in Fig. 2.

On 2 August 2000, an investigation team from the National Institute for the Improvement of Working Conditions and Environment (NICE) conducted working environment measurement. The company had already modified work practices. Two TCE tanks were emptied and the opened $200 \mathrm{ml}$ TCE containers were removed from polishing areas.

At the request of the team, the company demonstrated 
Table 1. Concentration of trichloroethylene measured by detector tube

\begin{tabular}{lc}
\hline \multicolumn{1}{c}{ Samping point } & $\begin{array}{c}\text { Trichloroethylene concentration } \\
\text { (Short term exposure level) }(\mathrm{ppm})\end{array}$ \\
\hline -Pouring TCE into tank & 35 \\
-Dipping & 15 \\
-Air drying & 30 \\
-Air drying & 40 \\
\hline
\end{tabular}

normal working scenario under this modified condition. Airborne TCE level was measured by a piston pump and commercial gas detector tubes (Gastec, detection range 5$100 \mathrm{ppm})$. The results are shown in Table 1. TCE concentrations were between 15 and $40 \mathrm{ppm}$ which were considered low comparing with the standard (TLV-STEL $100 \mathrm{ppm}, \mathrm{ACGIH})^{10)}$. Personal exposure levels were determined for seven workers by personal sampling pumps (Mine Safety Appliances Company in U.S.A., flow rate 200 $\mathrm{cc} / \mathrm{min}$, activated charcoal tube) for $1.5 \mathrm{~h}$ at the polishing line, final inspection and at the dipping process. Analysis with gas-chromatography revealed that the TCE levels were within the range of 3.08-12.23 ppm (TLV-TWA $50 \mathrm{ppm}$, ACGIH) ${ }^{10)}$ while $n$-hexane levels were between 4.32 and 20.67 ppm (TLV-TWA 50 ppm, ACGIH) ${ }^{10)}$ (Table 2).

Since we observed that there was a drinking water cooler for workers near to a TCE tank, we sampled the water and analyzed it with gas-chromatography. But TCE was not detected.

An epidemiological survey to identify health disorders due to TCE among other workers was conducted on 2 August 2000. From 344 employees, 183 exposed employees volunteered for health check up. According to questionnaire and physical examination, 24 workers (13.1\%) could be diagnosed as having dermatitis due to unspecified cause within the last two months. In the afternoon, 51 samples of urine were collected for TCA analysis. Twelve of them were excluded because of extremely low specific gravity (less than 1.010$)^{11)}$. TCA was detected from 26 out of 39 samples $(66.6 \%)$. The range was $6.07-87.02 \mathrm{mg} / \mathrm{g}$ creatinine with mean of 33.01 (BEI $100 \mathrm{mg} / \mathrm{g}$ creatinine, ACGIH) ${ }^{10}$.

All affected three individuals in Thailand were young, aged 18, 24 and 23, respectively, and healthy without history of drug allergy or alcohol consumption. In the present two cases, the clinical features characterized by generalized eruption, mucosal lesion and acute hepatitis, exposure condition to TCE, and latency period for four to five weeks from the initiation of exposure to the onset of illness coincided with those described in the previous papers ${ }^{1-9)}$.

The factory where the present two workers were employed had been operated for more than a decade. There had never been any similar cases, even among the heavy TCE exposure. Overall, the factory had little incentive to improve working conditions. The room where TCE was used was poorly ventilated. The TCE-dipped watchstraps were air-dried in the room. Besides, clothe masks and cloth gloves worn by workers were not effective for preventing TCE exposure since the worker could smell it and felt skin contact with liquid TCE. The risk of TCE exposure would be potentiated during summer due to increased evaporation of TCE at high room temperature $\left(>35^{\circ} \mathrm{C}\right)$. Working overtime also contributed greatly to TCE exposure.

According to the information on working conditions provided by the two workers and the company representatives, it was concluded that the two patients were exposed to TCE intensively during work. Working

Table 2. Concentrations of trichloroethylene and n-hexane in air and trichloroacetic acid in urine

\begin{tabular}{lccc}
\hline & \multicolumn{2}{c}{$\begin{array}{c}\text { Gas concentration } \\
\text { (Time weighted average) }(\mathrm{ppm})\end{array}$} & $\begin{array}{c}\text { Trichloroacetic acid in urine } \\
\text { (mg/g creatinine) }\end{array}$ \\
\cline { 2 - 3 } & Trichloroethylene & n-Hexane & \\
\hline Personal exposure monitoring & 3.78 & 15.34 & Not taken \\
-Polishing and dipping & 6.28 & 4.61 & 25.02 \\
-Pouring TCE and dipping & 3.44 & 1.57 & Not taken \\
-Final inspection & 5.45 & 17.12 & 24.00 \\
-Final inspection & 3.08 & 18.84 & Not taken \\
-Rough polishing & 4.07 & 20.67 & 31.48 \\
-Fine polishing & 12.23 & 4.32 & $\ldots \ldots \ldots$ \\
-On the table for dipping* & & & $\cdots \ldots .$. \\
\hline
\end{tabular}

*: A charcoal tube was set on a table of dipping process for comparison between trichloroethylene level at work area and that of breathing area. 
environment and urinary metabolite measurement after the modification of the workplace would be lower than those of the two cases' actual exposure level. Moreover, urine samplings for epidemiological survey, which were collected at middle instead of at the end of workweek, could provide underestimated results ${ }^{10)}$.

Although the causal relationship between occupational exposure to TCE and generalized eruption accompanied by acute hepatitis appeared definite, the substance responsible for the development of the illness has not yet been identified ${ }^{6,12)}$. The two patients developed their illnesses almost simultaneously in a company where TCE has been used for a long time. There have been studies reporting similar simultaneous occurrence of the illness ${ }^{1,3)}$. This fact might suggest the role of an unknown factor that did not usually exist in the workplace or a factor relevant to the susceptibility of the patients, neither of which could be identified.

Finally, we would like to disseminate the findings from this report to any workers exposed to TCE and to establish occupational health measures against illness in workplaces.

\section{Acknowledgements}

The author would like to thank Emeritus Prof. Yasuhiro Takeuchi and Associate Prof. Michihiro Kamijima of Nagoya University Graduate School of Medicine for their kind helps and invaluable advices also thanks to Dr. Ippei Mori and Dr. Naomi Hisanaga of National Institute of Industrial Health, and Prof. Hiroshi Jonai of Nippon University, Japan, who reviewed this paper.

\section{References}

1) Kubota S (1966) Trichloroethylene and skin disorder. Rodo no Kagaku 21, 45-7.

2) Bauer M, Rabens SF (1977) Trichloroethylene toxicity. Int J Dermatol 16, 113-6.

3) Phoon WH, Chan MOY, Rajan VS, Tan KJ,
Thirumoorthy T, Goh CL (1984) Stevens-Johnson syndrome associated with occupational exposure to trichloroethylene. Contact Dermatitis 10, 270-6.

4) Goh CL, Nq SK (1988) A cutaneous manifestation of trichloroethylene toxicity. Contact Dermatitis 34, 5961.

5) Nakayama H, Kobayashi M, Takahashi M, Ageishi Y, Takano T (1988) Generalized eruption with severe liver dysfunction associated with occupational exposure to trichloroethylene. Contact Dermatitis 19, 48-51.

6) Hisanaga N, Jonai H, Yu X, Ogawa Y, Mori I, Kamijima M, Ichihara G, Shibata E, Takeuchi Y (2002) StevensJohnson syndrome accompanied by acute hepatitis in workers exposed to trichloroethylene or tetrachloroethylene. San Ei Shi 44, 33-49.

7) Estrella-Gust DP, Cucueco MTS, Granadillos NG, Dumayag CM (1999) Outbreak of Stevens-Johnson syndrome (SJS) in an electronics company in the Philippines. Proceedings of 16th Asian Conference on Occupational Health in Cebu, the Philippines.

8) Huang HL, Li L, Chen B, Huang JX, Kuang SR (2002) New problems caused by occupational trichloroethylene exposure. Int J Immunopathol Pharmacol 15, 30-2.

9) Chittasobhaktra T, Wannanukul W, Wattanakrai $P$, Pramoolsinsap C, Sohonslitdsuk A, Nitiyanant P (1997) Fever, skin rash, jaundice and lymphadenopathy. J Med Assoc Thai 80 (Suppl 1), s144-8.

10) American Conference of Governmental Industrial Hygienists (1999) Threshold Limit Values for Chemical Substances and Physical Agents and Biological Exposure Indices, ACGIH, Cincinnati.

11) Rosenberg J, Harrison RJ (1997) Biological Monitoring. In: Occupational and environmental medicine. ed. by LaDou J, 637-46, Appleton \& Lange, Stanford.

12) Nakajima T, Yamanoshita O, Kamijima M, Kishi R, Ichihara G (2003) Generalized skin reactions in relation to trichloroethylene exposure: a review from the viewpoint of drug-metabolizing enzymes. J Occup Health 45, 8-14. 